\title{
Rancang Bangun CD Interaktif Pembelajaran Pengolahan Citra Digital Berbasis Multimedia Dengan Model Classic Tutorial
}

\author{
Kasman Rukun \\ Program Studi Pendidikan Teknik Informatika \\ Jurusan Teknik Elektronika \\ Fakultas Teknik - Universitas Negeri Padang \\ Padang - Indonesia \\ kasman.rukun@gmail.com
}

\author{
Asrul Huda \\ Program Studi Pendidikan Teknik Informatika \\ Jurusan Teknik Elektronika \\ Fakultas Teknik - Universitas Negeri Padang \\ Padang - Indonesia \\ asrulhuda@gmail.com
}

\author{
Yeka Hendriyani \\ Program Studi Pendidikan Teknik Informatika \\ Jurusan Teknik Elektronika \\ Fakultas Teknik - Universitas Negeri Padang \\ Padang - Indonesia \\ yecha_053@yahoo.co.id
}

\begin{abstract}
Abstrak-Pengolahan Citra Digital merupakan mata pelajaran wajib paket keahlian bagi siswa SMK jurusan Multimedia. Pembelajaran Pengolahan Citra Digital ini lebih mengarah pada kegiatan praktikum berbasis kompetensi dengan tujuan untuk memberikan bekal keterampilan yang kuat disertai dengan landasan teori yang realistis kepada siswa. Namun masih banyak terdapat beberapa siswa tidak menguasai dan memahami pelajaran yang diberikan guru dikarenakan metode yang digunakan guru dalam proses pembelajaran yang masih bersifat konvensional dan monoton. Untuk itu perlu untuk mengembangkan media pembelajaran yang dapat membantu siswa dalam menguasai materi berupa Multimedia Interaktif yang dikemas dalam sebuah $C D$.
\end{abstract}

Dalam perancangan materi digunakan model classic tutorial dan melalui prosedur teknis pembelajaran multimedia interaktif yaitu : Analisis kebutuhan, identifikasi materi, menentukan model pembelajaran, desain flow chart, penulisan story board, pengumpulan bahan grafis, pengumpulan bahan animasi, pemograman, finishing dan mastering, uji coba, revisi produk akhir. Pembuatan CD multimedia interaktif ini menggunakan software aplikasi Macromedia Director 2004 dan aplikasi pendukung lainnya. CD multimedia interaktif ini juga dilengkapi dengan test formatif untuk mengukur tingkat pengetahuan siswa terhadap materi yang telah dipelajari.

$C D$ multimedia interaktif pembelajaran dengan model classic tutorial mata pelajaran pengolahan citra digital diharapkan mampu memberikan kemudahan bagi siswa dalam proses pembelajarannya.

Kata Kunci-perancangan, media pembelajaran, $C D$ multimedia interaktif

\section{Pendahuluan}

Pembelajaran merupakan komunikasi atau penyampaian pesan pengetahuan yang ditujukan kepada peserta didik. Untuk memperlancar dan mempermudah penyampaian pesan dan informasi tersebut, maka diperlukan media pembelajaran yang dapat merangsang pikiran, perasaan, minat dan perhatian peserta didik.

Perkembangan teknologi dan informasi memberikan pengaruh besar terhadap kemajuan dunia pendidikan.Diantara pengaruh teknologi dan informasi pada dunia pendidikan adalah penggunaan media pembelajaran yang terus berkembang mengikuti perkembangan teknologi, khususnya perkembangan teknologi komputer dalam bidang multimedia dan bahasa pemograman.

Namun pada sisi lain, penggunaan media pembelajaran masih belum optimal digunakan oleh pendidik, karena masih belum mempertimbangkan faktor kemudahan penggunaan secara efektif dan efesien. Padahal dukungan teknologi komputer, pembelajaran dapat dilakukan lebih fleksibel dengan waktu dan ruang.Siswa tidak dituntut hadir pada setiap kegiatan pembelajaran, karena mereka dapat mempelajari materi pembelajaran melalui multimedia kapan saja dan dimana saja selama terdapat multimedia.

Sekolah Menengah Kejuruan (SMK) adalah salah satu lembaga pendidikan yang memiliki peran sangat 
penting dalam mencerdaskan dan meningkatkan sumber daya manusia yang memiliki kemampuan dalam bidang keteknikan berdasarkan Kurikulum Tingkat Satuan Pendidikan. Peraturan Pemerintah Republik Indonesia Nomor 19 Tahun 2005 Tentang Standar Nasional Pendidikan Pasal 26 ayat (3), pendidikan menengah kejuruan bertujuan untuk meningkatkan kecerdasan, pengetahuan, kepribadian, ahklak mulia, serta keterampilan untuk hidup mandiri dan mengikuti pendidikan lebih lanjut sesuai dengan kejuruannya.

Sekolah Menengah Kejuruan Negeri (SMK) Kabupaten Dharmasraya merupakan salah satu lembaga pendidikan juga bertanggung jawab dan berperan dalam mencerdaskan dan meningkatkan sumber daya manusia yang memiliki kemampuan dalam bidang keterampilan dan keteknikan. Namun berdasarkan pengamatan dan observasi sementara penulis di SMK Kabupaten Dharmasraya, masih banyak terdapat beberapa siswasiswi tidak menguasai dan memahami pelajaran yang diberikan guru kepada mereka. Hal tersebut dapat dilihat dari metode yang digunakan guru dalam proses pembelajaran yang masih bersifat konvensional dan monoton sehingga banyak diantara siswa kurang perhatian terhadap materi yang diberikan guru. Disamping itu, ada sebagian guru tidak memanfaatkan IT dalam menunjang proses pembelajarannya.

Dalam mengatasi permasalahan di atas, maka diperlukan inovasi pembelajaran yang lebih mudah diterima dan menarik oleh siswa.Salah satu solusinya adalah penggunaan media pembelajaran berupa media interaktif.

Asyar menyebutkan (2011:92),bahwa dalam pemanfaatan media, selain kreativitas pendidik, pertimbangan instruksional juga menjadi salah satu faktor yang menentukan. Pemanfaatan media pembelajaran berkaitan erat dengan peningkatan kualitas pembelajaran yang diharapkan. Pemanfaatan media pembelajaran oleh guru diharapkan dapat menciptakan pengalaman belajar yang lebih bermakna, memfasilitasi proses interaksi antara siswa dengan guru dan siswa yang releven dimana saja, serta memperkaya pengalaman belajar siswa. Hal ini dipercaya mampu mengubah suasana belajar yang pasif. Siswa aktif berdiskusi dan mencari melalui beragam sumber belajar yang tersedia, sementara guruberperan menjadi fasilitator yang sama-sama terlibat dalam proses belajar. Ketersediaan akan keanekaragaman media dan teknologi pembelajaran dapat membantu siswa secara luwes untuk mencapai tujuan belajarnya.

Pengembangan media interaktif sangat penting untuk mengatasi kekurangan dan keterbatasan persediaan media yang ada. Media yang dikembangkan sendiri oleh guru dapat mengoptimalkan penguasaan materi oleh siswa. Lebih dari itu, juga dapat meningkatkan kreativitas dan kemampuan inovasi para guru sehingga guru profesional.

Penggunaan media interaktif merupakan salah satu solusi yang mempunyai peranan yang penting. Pemilihan media interaktif yang tepat, yaitu yang sesuai dengan materi yang akan disampaikan dengan tujuan yang akan dicapai, merupakan salah satu kunci keberhasilan suatu proses belajar mengajar.

Computer based training adalah perangkat lunak atau software yang merupakan salah satu aplikasi kecerdasan buatan yang memanfaatkan komputer untuk menjadi tutor yang dapat melatih dan mengajar. Berbeda dengan aplikasi pembelajaran konvensional yang hanya mempresentasikan urutan materi instruksional yang sudah terkemas, sehingga tidak dapat membedakan kemampuan siswa sebagai user. Pada computer based training penyampaian materi layaknya seperti guru atau tutor yang dapat menyesuaikan dengan kemampuan pemahaman siswa sebagai user, karena pembelajaran merupakan suatu sistem yang mengandung komponen-komponen yang saling berkaitan untuk mencapai tujuan yang telah ditetapkan. Komponenkomponen tersebut meliputi: tujuan, materi, metode, media dan evaluasi. Materi yang dijadikan obyek pembelajaran dalam perancangan media pembelajaran ini adalah Pengolahan Citra Digital yang sesuai dengan kurikulum 2013.

Pengolahan citra digital merupakan mata pelajaran keahlian Jurusan Multimedia untuk kelas XI semester 1. Dalam materi ini siswa dituntut untuk sering melakukan latihan agar dapat memahami konsep dan menggunakan konsep tersebut dalam praktikum dengan berbagai model dan bentuk latihan. Dalam penyampaian materi, biasanya guru menggunakan metode ceramah dan mempraktekkan teori tersebut menggunakan layar proyektor sementara itu siswa mengikuti apa yang dilakukan guru. Namun, dalam kenyataannya tidak semua siswa tersebut bisa melakukan apa yang dilakukan oleh guru. Hal tersebut bisa saja disebabkan oleh beberapa faktor antara lain : berbedanya intelektual siswa terhadap pemahaman suatu materi, guru terlalu cepat menerangkan, konsentrasi siswa terganggu karena adanya kerusakan komputer, siswa terlambat mengikuti instruksi guru, siswa lupa dengan materi yang telah diajarkan sehingga dalam latihan siswa tidak bisa menggunakan metode-metode yang telah diajarkan guru dan siswa terus bertanya mengenai materi tersebut.

Atas dasar kenyataan inilah, maka perlu dicari alternatif dengan melakukan inovasi dan pendekatan, baik dalam penggunaan media ataupun metode penyampaian sehingga proses pembelajaran dapat berlangsung aktif, kreatif, efektif dan menyenangkan. Untuk itu perlu dirancang media pembelajaran berbasis multimedia interaktif dengan model pembelajaran classic 
tutorial. Maka dari itu, penulis menuangkannya dalam bentuk Tugas Akhir dengan judul "Rancang Bangun CD Interaktif Pembelajaran Pengolahan Citra Digital Berbasis Multimedia Dengan Model Classic Tutorial Pada Kelas XI Jurusan Multimedia SMK Kabupaten Dharmasraya"

Pengertian multimedia dalam jurnal Septiana, dkk. (2012) menurut beberapa ahli yaitu Rosch: "Multimedia adalah kombinasi dari komputer dan video"; Adapun pengertian menurut McCornick: "Multimedia secara umum merupakan kombinasi tiga elemen, yaitu suara, gambar dan teks"; Menurut Turban dkk: "Multimedia adalah kombinasi dari paling sedikit dua media input atau output dari data, media ini dapat audio (suara, musik), animasi, video, teks, grafik dan gambar" Menurut Robin dan Linda: "Multimedia merupakan alat yang dapat menciptakan presentasi yang dinamis dan interaktif yang mengkombinasikan teks, grafik, animasi, audio, gambar video".

"CD Interaktif terdiri dari kata CD dan Interaktif. CD adalah media penyimpanan data yang merupakan singkatan dari Compatct Disc. Sedangkan interaktif adalah komunikasi 2 arah atau disebut juga dialog. Dua arah maksudnya adalah kita ikut aktif untuk menentukan jalannya materi seperti pada game dan website". (Hendi, 2008:340).

"Secara umum, pengolahan citra digital menunjuk pada pemrosesan gambar 2 dimensi menggunakan computer. Dalam konteks yang lebih luas, pengolahan citra digital mengacu pada pemrosesan setiap data 2 dimensi" (Darma, 2010:19). Lebih lanjut (Tabratas, 2003:12) dalam buku (Darma, 2010:19) mengemukakan "Citra adalah representasi informasi dua dimensi yang diciptakan atau dibuat dengan melihat atau lebih tepatnya merasakan sebuah gambar atau pemandangan".

Pengertian dari desain grafis adalah salah satu bentuk seni lukis (gambar) terapan yang memberikan kebebasan kepada sang desainer (perancang) untuk memilih, menciptakan, atau mengatur elemen rupa seperti ilustrasi, foto, tulisan, dan garis di atas suatu permukaan dengan tujuan untuk diproduksi dan dikomunikasikan sebagai pesan. Gambar maupun tanda yang digunakan biasa berupa tipografi atau media lainnya, Desain grafis umumnya diterapkan dalam dunia periklanan, packaging, perfilman, dan lain-lain.

Desain grafis menurut Hendi (2006:3) adalah "sebagai proses pemikiran yang diwujudkan dalam gambar". Termasuk dalam memilih unsur-unsur tersebut kemudian mengubahnya menjadi suatu bentuk yang mengandung kaidah, rasa nilai estetik dari wujud yang diinginkan.
Menurut Deni (2012:20), prosedur teknis pembelajaran multimedia interaktif adalah sebagai berikut :

1. Analisis Kebutuhan

2. Identifikasi Materi

3. Menentukan Model Pembelajaran

4. Desain Flow Chart

5. Penulisan Story Board

6. Pengumpulan Bahan Grafis

7. Pengumpulan Bahan Animasi

8. Pemrograman

9. Finishing, Mastering

10. Uji coba

11. Revisi produk akhir

Secara visual alur dari tahapan teknis mulai dari langkah 1 sampai dengan langkah ke-11, dapat dirangkum pada bagan berikut ini :

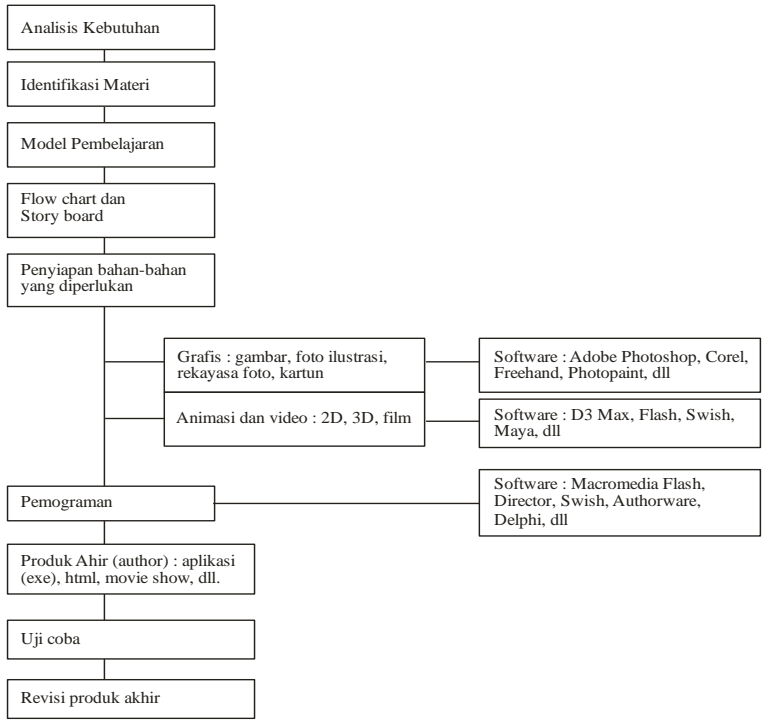

Gambar 1. Prosedur Teknis Pengembangan Program Multimedia

\section{Analisis Perancangan}

Berdasarkan analisis karakteristik materi dan tujuan serta identifikasi materi, penulis menentukan model CBI (computer based instruction) pembelajaran classic tutorial, dimana terdapat 7 (tujuh) identitas model tutorial dalam pembelajaran berbasis komputer, yaitu :

1. Pengenalan (introduction) : Pengenalan terhadap aplikasi tersebut.

2. Penyajian informasi (presentation of information): Penyajian informasi bagi pengguna dalam bentuk materi untuk menggunakan aplikasi tersebut.

3. Pertanyaan dan respon (question and responses): Memberi pertanyaan kemudian aplikasi memberi respon yang berbentuk keterangan dan penilaian (scoring).

4. Penilaian respon (judging responses) : Memberi penilaian (scoring). 
5. Pemberian feedback tentang respon (providing feedback about responses): Setelah pengguna mendapat keterangan atas hasil yang diperoleh dalam menjawab pertanyaan dan respon yang diberi maka aplikasi tersebut memberi feedback dalam bentuk saran untuk pengguna.

6. Pembetulan (remediation): Pembetulan dapat dilakukan setelah pengguna membuka kunci jawaban.

7. Penutup (clossing): Aplikasi selesai dijalankan.

Adapun flowchart dalam perencanaan dan pembuatan CD multimedia interaktif adalah sebagai berikut:

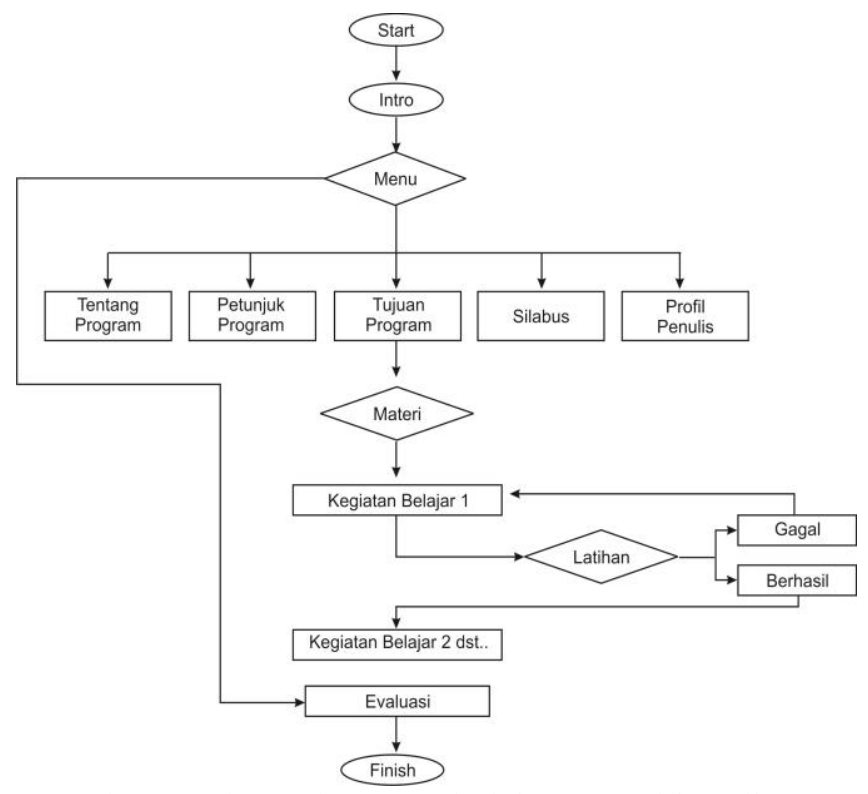

Gambar 2. Flow Chart Pembelajaran Multimedia Interaktif

Dari disain flow chart di atas dapat dilihat bahwa CD dimulai dari pembuka (intro) kemudian masuk ke menu program.Dalam halaman menu program terdapat 7 tombol yaitu tentang program, petunjuk program, tujuan program, silabus, profil penulis, evaluasi.Materi disusun berdasarkan 18 kegiatan belajar.Pada setiap akhir kegiatan pembelajaran, siswa dituntut untuk melakukan evaluasi terhadap materi - materi yang telah dipelajari.

Dalam memproduksi program multimedia pembelajaran model tutorial langkah selanjutnya yang harus ditempuh yaitu membuat storyboard. Tahapan proses produksi dapat dilihat pada tabel berikut ini :

Tabel 1. Komponen CD Multimedia Interaktif

\begin{tabular}{|c|l|l|l|}
\hline No. & Halaman & \multicolumn{1}{c|}{ Visual } & \multicolumn{1}{c|}{ Audio } \\
\hline 1. & Intro / & Animasi logo Tut & Opening \\
& opening & $\begin{array}{l}\text { Wuri Handayani. } \\
\text { Judul program } \\
\text { Tombol "masuk" ke }\end{array}$ & $\begin{array}{l}\text { sound } \\
\text { effect }\end{array}$ \\
\hline
\end{tabular}

\begin{tabular}{|c|c|c|c|}
\hline No. & Halaman & Visual & Audio \\
\hline & & $\begin{array}{l}\text { halaman "Menu } \\
\text { Utama" }\end{array}$ & \\
\hline 2. & $\begin{array}{l}\text { Menu } \\
\text { Utama }\end{array}$ & $\begin{array}{l}\text { Halaman ini berisi } \\
\text { kumpulan menu yang } \\
\text { dapat diakses oleh } \\
\text { siswa. } \\
\text { Menu-menu yang } \\
\text { ditampilkan : } \\
\text { 1. Tentang program } \\
\text { 2. Petunjuk } \\
\text { program } \\
\text { 3. Tujuan program } \\
\text { 4. Silabus } \\
\text { 5. Profil penulis } \\
\text { 6. Materi } \\
\text { 7. Evaluasi } \\
\text { Apabila menu diklik } \\
\text { maka tulisan menu } \\
\text { akan berubah warna } \\
\text { dan pindah ke } \\
\text { halaman yang dituju. } \\
\text { Pada halaman ini } \\
\text { ditampilkan animasi } \\
\text { karya-karya design } \\
\text { grafis. } \\
\text { Sementara animasi } \\
\text { karya-karya desain } \\
\text { grafis ditampilkan, } \\
\text { penulis } \\
\text { mengucapkan kata } \\
\text { pengantar untuk } \\
\text { siswa. }\end{array}$ & $\begin{array}{l}\text { sound } \\
\text { effect } \\
\text { Narrator : } \\
\text { Kata } \\
\text { Pengantar } \\
\text { Selamat } \\
\text { datang } \\
\text { dalam } \\
\text { media } \\
\text { pembelajar } \\
\text { an } \\
\text { multimedia } \\
\text { interaktif. } \\
\text { Dalam } \\
\text { program ini } \\
\text { kita akan } \\
\text { mempelajar } \\
\text { i materi } \\
\text { mengenai } \\
\text { pengolahan } \\
\text { citra digital } \\
\text { dengan } \\
\text { menggunak } \\
\text { an software } \\
\text { Coreldraw } \\
\text { 13 \& } \\
\text { Adobe } \\
\text { Photoshop } \\
\text { CS } 3 \text {. } \\
\text { Materi ini } \\
\text { diperuntuk } \\
\text { kan bagi } \\
\text { siswa SMK } \\
\text { Multimedia } \\
\text { kelas XI } \\
\text { semester } \\
\text { 2dengan } 18 \\
\text { kegiatan } \\
\text { belajar. } \\
\text { Sebelum } \\
\text { masuk ke } \\
\text { materi, } \\
\text { siswa } \\
\text { diharapkan } \\
\text { membaca } \\
\text { petunjuk } \\
\text { dan tujuan } \\
\text { program, } \\
\text { supaya } \\
\text { siswa lebih }\end{array}$ \\
\hline
\end{tabular}




\begin{tabular}{|c|c|c|c|}
\hline No. & Halaman & Visual & Audio \\
\hline & & & $\begin{array}{l}\text { memahami } \\
\text { apa yang } \\
\text { akan } \\
\text { dipelajari } \\
\text { selanjutnya. }\end{array}$ \\
\hline 3. & $\begin{array}{l}\text { Tentang } \\
\text { Program }\end{array}$ & $\begin{array}{l}\text { Media Pembelajaran } \\
\text { "Pengolahan citra } \\
\text { digital" merupakan } \\
\text { media pembelajaran } \\
\text { jurusan SMK } \\
\text { multimedia untuk } \\
\text { kelas XI Semester } 2 . \\
\text { Media ini berfungsi } \\
\text { sebagai software } \\
\text { pembelajaran } \\
\text { mandiri yang dapat } \\
\text { digunakan oleh siswa } \\
\text { untuk belajar secara } \\
\text { mandiri. Media ini } \\
\text { membahas tentang } \\
\text { penggunaan software } \\
\text { Coreldraw } 13 \text { \& } \\
\text { Adobe Photoshop CS } \\
3 \text { serta aplikasinya } \\
\text { dalam dunia } \\
\text { advertising. }\end{array}$ & $\begin{array}{l}\text { sound } \\
\text { effect }\end{array}$ \\
\hline 4. & $\begin{array}{l}\text { Petunjuk } \\
\text { Program }\end{array}$ & $\begin{array}{l}\text { 1. Program } \\
\text { pembelajaran ini } \\
\text { disajikan tiap } \\
\text { pertemuan yang } \\
\text { didalamnya berisi } \\
\text { : } \\
\text { a. Tujuan } \\
\text { Pembelajaran } \\
\text { b. Materi } \\
\text { pembelajaran } \\
\text { c. Test formatif } \\
\text { 2. Pahami dengan } \\
\text { baik materi yang } \\
\text { disajikan. } \\
\text { 3. Ikuti petunjuk } \\
\text { yang diberikan } \\
\text { oleh tutor. }\end{array}$ & $\begin{array}{l}\text { sound } \\
\text { effect }\end{array}$ \\
\hline 5. & $\begin{array}{l}\text { Tujuan } \\
\text { Pembelaja } \\
\text { ran }\end{array}$ & $\begin{array}{l}\text { Setelah mempelajari } \\
\text { uraian materi dalam } \\
\text { bab pembelajaran } \\
\text { dan kegiatan } \\
\text { belajar diharapkan } \\
\text { peserta didik dapat } \\
\text { memiliki kompetensi }\end{array}$ & $\begin{array}{l}\text { sound } \\
\text { effect } \\
\text { Narasi }\end{array}$ \\
\hline
\end{tabular}

\begin{tabular}{|c|c|c|c|}
\hline No. & Halaman & Visual & Audio \\
\hline & & $\begin{array}{l}\text { sikap, pengetahuan } \\
\text { dan ketrampilan yang } \\
\text { berkaitan dengan } \\
\text { materi: } \\
\text { 1. Citra vektor } \\
\text { 2. Aplikasi } \\
\text { pengolah citra } \\
\text { vektor } \\
\text { 3. Penggabungan } \\
\text { gambar bitmap } \\
\text { 4. Pemberian efek } \\
\text { pada gambar } \\
\text { bitmap }\end{array}$ & \\
\hline 6. & Silabus & $\begin{array}{l}\text { Berisi KI - KD } 1 \\
\text { (satu semester) yang } \\
\text { akan dibuat dalam } \\
\text { tugas akhir ini. }\end{array}$ & $\begin{array}{l}\text { sound } \\
\text { effect }\end{array}$ \\
\hline 7. & Materi & $\begin{array}{l}\text { Terdiri dari } 18 \\
\text { kegiatan } \\
\text { belajar.Materi terdiri } \\
\text { dari teori dan } \\
\text { praktek, disajikan } \\
\text { dengan animasi dan } \\
\text { tutorial. }\end{array}$ & $\begin{array}{l}\text { sound } \\
\text { effect }\end{array}$ \\
\hline 8. & Evaluasi & $\begin{array}{l}\text { Berisi kumpulan soal } \\
\text { yang akan menguji } \\
\text { pemahaman siswa } \\
\text { mengenai materi } \\
\text { yang sudah } \\
\text { dipelajari. } \\
\text { Evaluasi ini } \\
\text { dilakukan setelah } \\
\text { siswa mempelajari } \\
\text { semua kegiatan } \\
\text { belajar. Soal yang } \\
\text { akan diberikan } \\
\text { berupa objektif } \\
\text { sebanyak } 50 \text { soal. } \\
\text { Pada akhir evaluasi, } \\
\text { siswa diberikan skor } \\
\text { nilai. }\end{array}$ & $\begin{array}{l}\text { sound } \\
\text { effect }\end{array}$ \\
\hline
\end{tabular}

Secara umum rancangan tampilan CD Multimedia Interaktif untuk mata pelajaran Pengolahan Citra Digital sebagai berikut : 


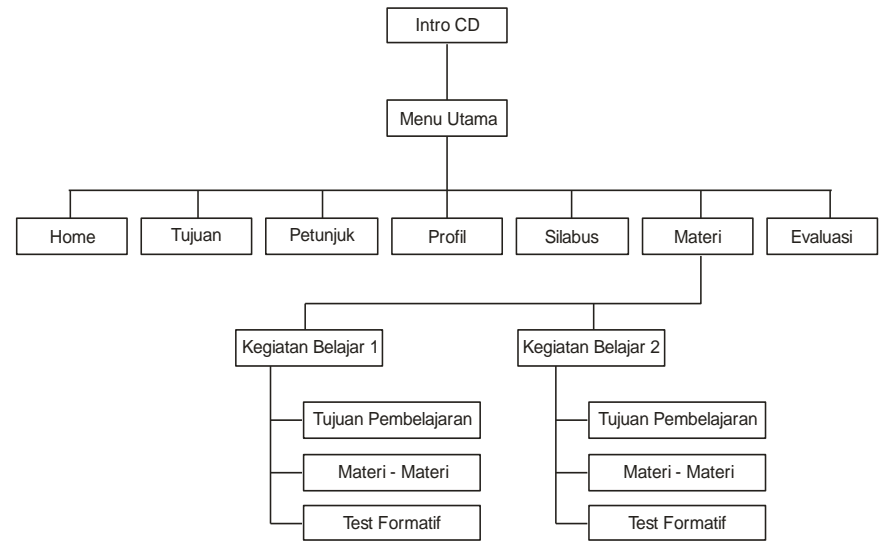

Gambar 3. Rancangan Menu Program

Intro merupakan menu awal yang otomatis terbuka ketika CD multimedia interaktif mata pelajaran Pengolahan Citra Digital dimasukkan ke dalam CD Rom. Kemudian akan terdapat link yang akan menuju halaman menu utama.

Di dalam menu utama terdapat 7 tombol navigasi yang akan link ke menu home, tujuan, petunjuk, profil, silabus, materi, evaluasi. Menu home merupakan menu pembuka yang berisi animasi karya-karya design grafis. Menu tujuan merupakan penjelasan tentang kompetensi yang akan dicapai setelah siswa mempelajari cd interaktif ini. Menu petunjuk berisi penjelasan mengenai petunjuk penggunaan program. Menu profil merupakan biodata penulis, menu silabus berisi uraian materi yang akan dipelajari siswa, menu materi merupakan menu yang link ke halaman menu materi yang di dalamnya terdapat 18 tombol kegiatan belajar, menu evaluasi untuk mengakses soal-soal objectif.

\section{Rancangan Antar Muka}

a. Halaman Intro, halaman pertama yang akan aktif autorun pada saat CD dimasukkan ke dalam cd rom.

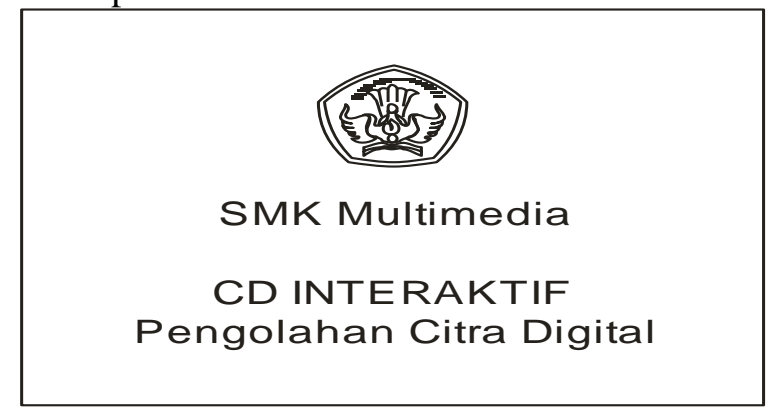

Gambar 4. Rancangan Halaman Intro

b. Halaman menu utama, terdiri dari 7 (tujuh) menu seperti yang terlihat pada gambar berikut :

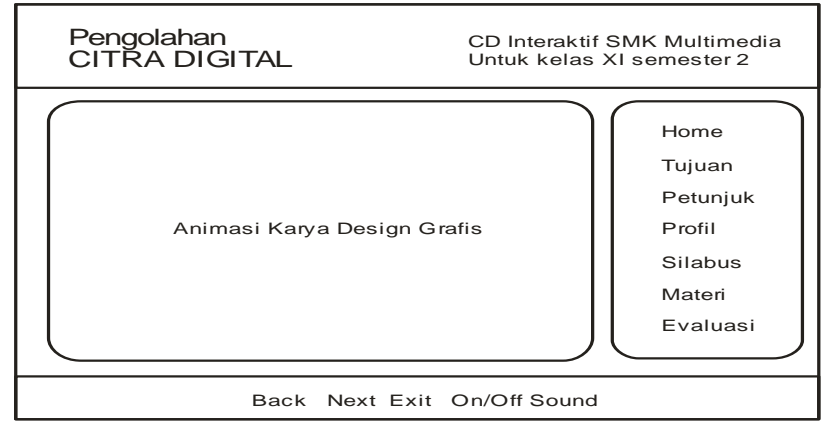

Gambar 5. Rancangan Halaman Menu Utama

c. Halaman menu materi, terdiri dari 16 tombol kegiatan belajar yang terlihat pada gambar berikut :

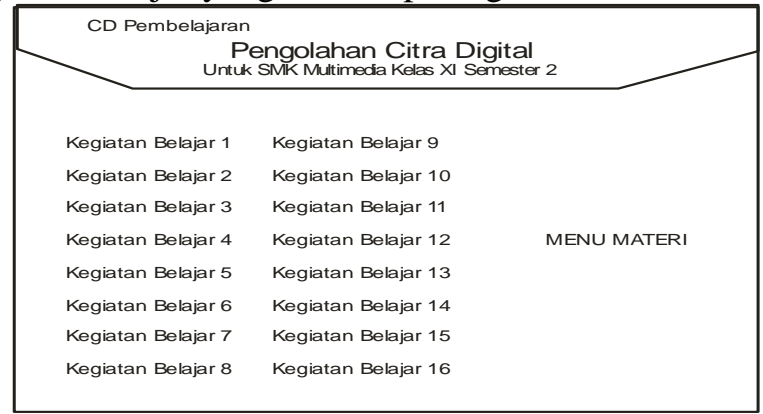

Gambar 6. Rancangan Halaman Menu Materi

d. Halaman Materi, terdiri dari 6 (enam) tombol yaitu tombol menu utama, tombol lanjut, tombol kembali, tombol keluar, tombol on/off sound dan tombol kembali ke menu materi yang terlihat pada gambar berikut :

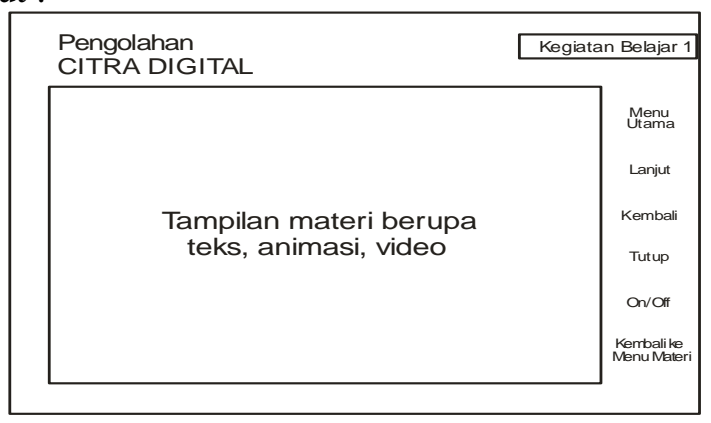

Gambar 7. Rancangan Halaman Materi

e. Halaman evaluasi, untuk mengakses soal-soal evaluasi yang terdapat di CD multimedia interaktif, seperti yang terlihat pada gambar berikut :

\begin{tabular}{|l|l|}
\hline EVALUASI \\
\hline \\
$\qquad$ Soal - Soal \\
\hline $\begin{array}{l}\text { Kembali ke } \\
\text { Menu Utama }\end{array}$ \\
\hline
\end{tabular}




\section{Gambar 8. Rancangan Halaman Evaluasi}

Pada halaman evaluasi ini diberikan pernyataan bahwa jika jawaban benar, maka nilai bertambah satu lalu menuju soal berikutnya. Jika jawaban salah maka hanya menuju halaman berikutnya saja tanpa ada penambahan nilai. Pada halaman akhir, ditampilkan nilai akhir dari semua pertanyaan yang telah dilewati.

\section{HaSil DAN PEMbahasan}

Hasil rancangan tampilan merupakan rancangan antarmuka CD multimedia interaktif. Setiap stage memiliki ukuran movie 1024 x 768 pixel dengan background hitam. Tampilan rancangan inilah yang merealisasikan terjadinya interaksi antara manusia dengan komputer. Hasil rancangan tampilan dapat dijelaskan di dalam point-point berikut ini :

\section{Halaman Intro}

Halaman Intro merupakan halaman yang menggambarkan proses masuk halaman menu utama. Intro dilengkapi dengan animasi yang dirancang menggunakan Adobe After Effect berdurasi 7 detik. Halaman ini terletak di dalam file Halaman Intro.exe. Gambar halaman awal intro adalah sebagai berikut.

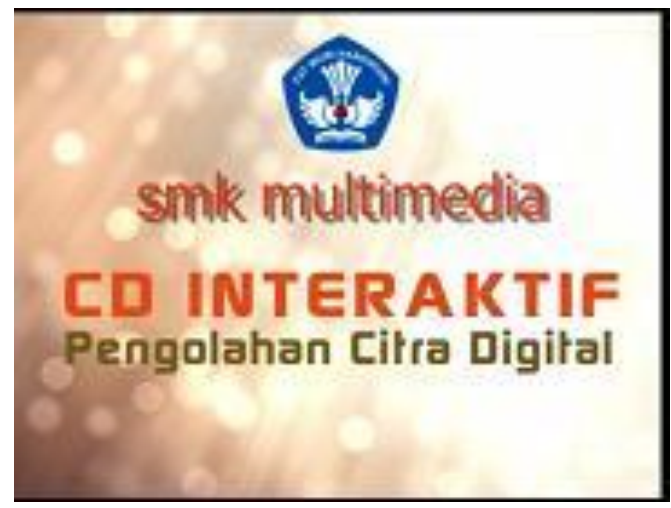

Gambar 9. Tampilan Halaman Intro

\section{Halaman Menu Utama}

Halaman menu utama merupakan halaman awal CD multimedia interaktif yang memiliki sebelas tombol navigasi. Susunan dari menu ini memakai sistem hirarki atau sequential menu yaitu di dalam halaman menu utama terdapat link ke menu materi dan dalam menu materi terdapat pula link ke materi-materi yang akan ditampilkan. Halaman ini terletak di dalam file
Halaman Utama.dir. Gambaran halaman Menu Utama dapat dilihat pada gambar berikut.

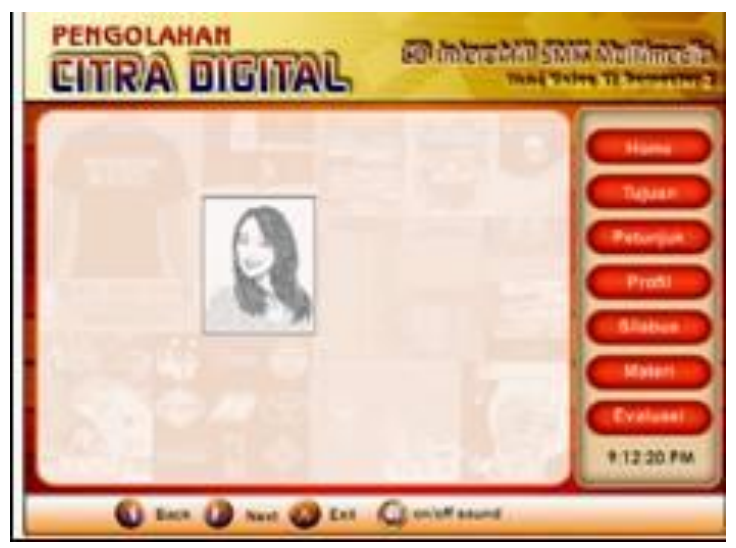

Gambar 10. Tampilan Halaman Menu Utama

Terdapat sebelas tombol navigasi di halaman menu utama ini. Fungsi masing-masing tombol dijelaskan pada point-point berikut ini.

a. Tombol Home. Tombol navigasi ini digunakan untuk menampilkan animasi hasil karya desain grafis dari pengolahan citra digital tersebut dan berisi narasi dari penulis yang merupakan ucapan selamat datang untuk user.

b. Tombol Tujuan. Tombol navigasi ini digunakan untuk menampilkan tujuan umum dari materi pembelajaran pengolahan citra digital ini. Halaman ini terletak di dalam file Halaman Utama.dir. Gambaran halaman tujuan adalah sebagai berikut.

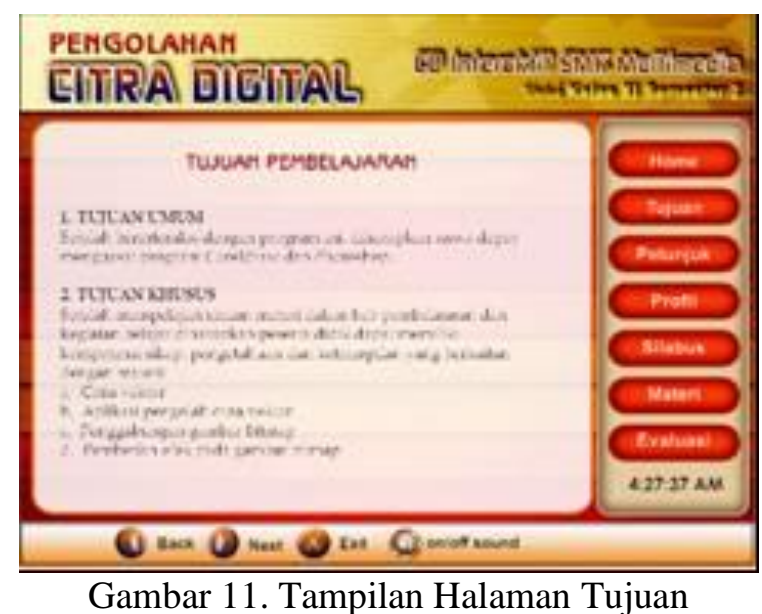

c. Tombol Petunjuk. Tombol navigasi ini digunakan untuk menampilkan petunjuk bagi user dalam mempelajari materi pengolahan citra digital ini. Halaman ini terletak di dalam file Halaman Utama.dir. Gambaran halaman petunjuk adalah sebagai berikut. 


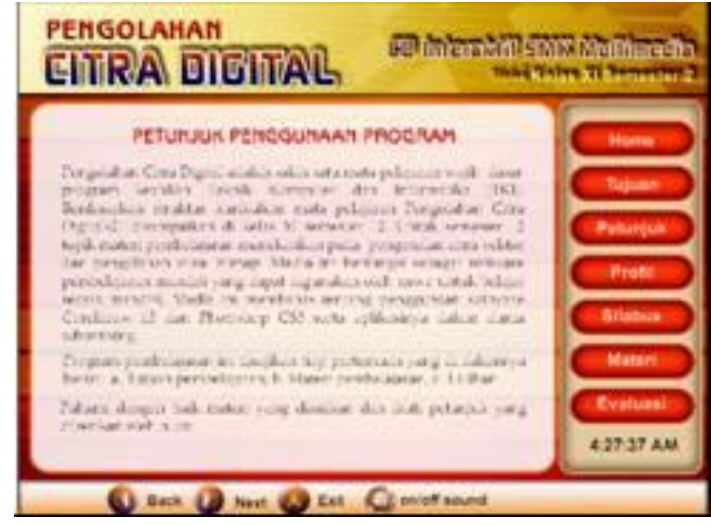

Gambar 12. Tampilan Halaman Petunjuk

d. Tombol Silabus. Tombol ini digunakan untuk menampilkan silabus bagi user dalam mempelajari materi pengolahan citra digital ini. Halaman ini terletak di dalam file Halaman Utama.dir. Gambaran halaman profil adalah sebagai berikut.

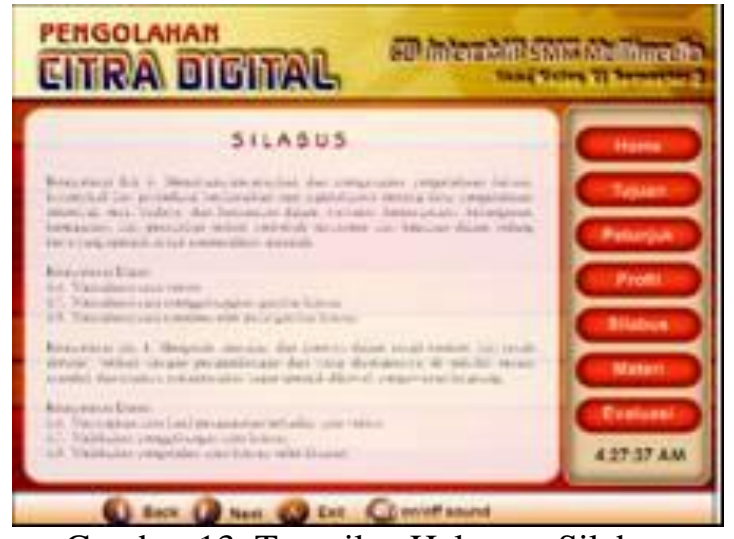

Gambar 13. Tampilan Halaman Silabus

Keterangan Gambar :

$>$ Tombol Materi : Tombol ini digunakan untuk menuju halaman Menu Materi yang berisi tomboltombol untuk akses ke materi kegiatan belajar. Halaman ini terletak di dalam file Halaman Menu Materi.dir. Gambaran halaman menu materi adalah sebagai berikut.

> Tombol Evaluasi : Tombol ini digunakan untuk menuju Halaman Evaluasi yang mana digunakan untuk menguji kemampuan siswa setelah mempelajari semua kegiatan belajar dalam cd interktif ini.

$>$ Tombol Next : Tombol ini digunakan untuk menuju halaman berikutnya pada halaman menu materi ini.

$>$ Tombol Back: Tombol ini digunakan untuk menuju halaman sebelumnya pada halaman menu materi ini.

> Tombol Exit. : Tombol ini digunakan untuk keluar dari CD multimedia interaktif. Tombol ini akan mengantarkan pengguna keluar secara otomatis.
$>$ Tombol Sound : Tombol ini digunakan untuk menghentikan dan menghidupkan suara dalam halaman menu utama ini.

Halaman materi merupakan halaman yang paling utama dalam cd multimedia interaktif ini. Penulis menyajikan menu materi ini menggunakan model hirarki. Sebelum siswa memulai kegiatan belajarnya, siswa tersebut terlebih dahulu harus memilih salah satu tombol kegiatan belajar yang mana dalam tombol tersebut terdapat menu-menu materi yang akan ditampilkan. Siswa bisa memilih salah satu materi yang diinginkannya seperti gambar berikut ini.

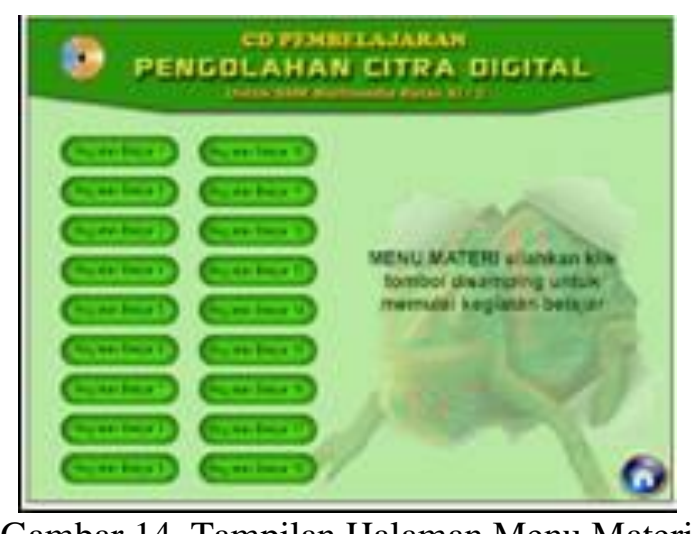

Gambar 14. Tampilan Halaman Menu Materi

Pewarnaan yang diberikan pada halaman ini adalah hijau tua dan muda. Background berupa tekstur dan gambar iguana yang merupakan icon dari Coreldraw 13 . Warna tombol menu adalah hijau muda. Tombol menu disusun vertikal seperti menu pull down dan tampilan menu materi terletak di sebelah kanan halaman. Pada halaman ini hanya diberikan tombol navigasi ke menu utama.

Halaman menu materi ini terdapat delapan belas tombol navigasi kegiatan belajar, masing-masing kegiatan belajar memiliki bagian judul, tujuan pembelajaran, materi dan test formatif. Satu kegiatan belajar bisa memiliki satu atau lebih judul materi yang ditunjukkan pada gambar di bawah ini.

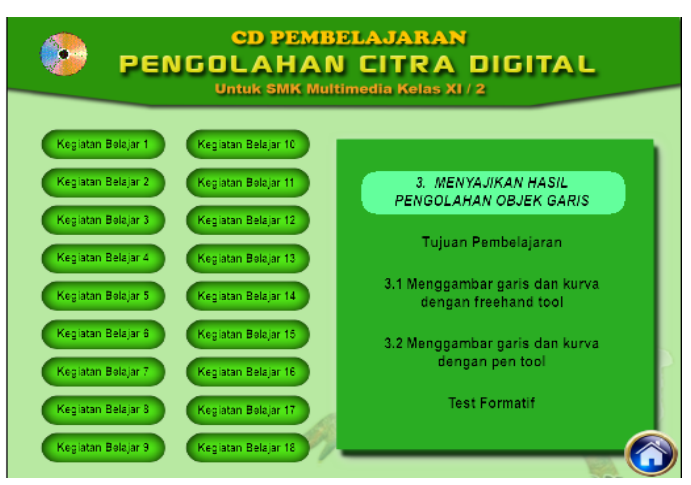

Gambar 15. Tampilan Halaman Materi 
Pada gambar di atas adalah tampilan menu dari kegiatan belajar 1 yang terdiri dari judul materi, tujuan pembelajaran, dua sub judul materi dan test formatif. Setiap tombol menu diklik, warna menu yang sedang ditunjuk mouse akan berubah menjadi hijau muda. Dalam halaman materi ini tersedia berbagai macam tombol sebagai navigasi user untuk melihat materi yang tersedia. Materi yang tersedia disusun berdasarkan silabus yang sudah dibuat sebelumnya. Beberapa materi disajikan menggunakan fasilitas video pembelajaran sehingga ini akan memudahkan siswa dalam proses pembelajaran. Berikut tampilan salah satu video materi pembelajaran yang tersedia.

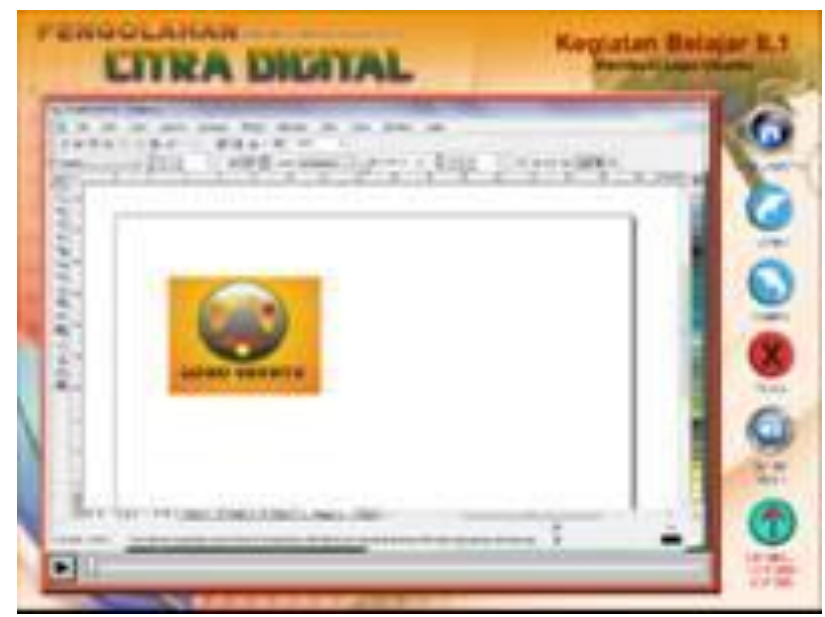

Gambar 16. Tampilan Halaman Materi Video

\section{Halaman Evaluasi}

Menu evaluasi terdapat dalam menu utama digunakan untuk mengevaluasi pembelajaran yang telah dilakukan sehingga dapat disimpulkan sejauh mana peningkatan kemampuan siswa dalam menerima pembelajaran yang telah dilakukan. Adapun gambar hasil rancangan evaluasi pembelajaran adalah sebagai berikut ini.

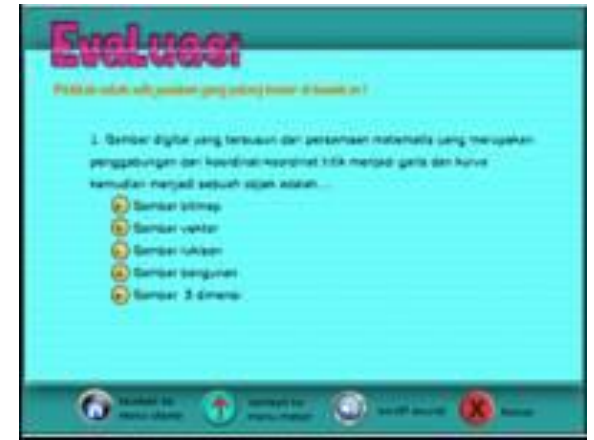

Gambar 17. Tampilan Halaman Evaluasi

Dalam halaman evaluasi ini disajikan 50 (lima puluh) butir soal. Setiap menjawab pertanyaan, siswa dapat mengklik tombol option berwarna kuning yang apabila tombol option sudah diklik maka akan lanjut soal nomor dua sampai soal nomor lima puluh. Setelah siswa selesai menjawab pertanyaan, maka akan muncul hasil skor dari jawaban yang telah diberikan.
Perancangan CD Multimedia Interaktif ini tidak cukup dengan desain tampilan saja. Setiap aplikasi yang digunakan untuk perancangan perangkat lunak menggunakan bahasa pemograman tertentu dalam penggunaannya. Perancangan CD Multimedia Interaktif ini banyak dititek beratkan pada penggunaan aplikasi Macromedia Director 10.

Action Script merupakan salah satu bahasa pemograman yang digunakan dalam perancangan perangkat lunak, khususnya untuk Macromedia Director. Kolaborasi antara desain tampilan dengan Action Script akan menghasilkan sebuah CD Multimedia Interaktif yang menarik. Penjelasan mengenai penggunaan Action Script yang digunakan di dalam CD Multimedia Interaktif ini adalah sebagai berikut.

\section{- Action Script masuk ke halaman menu utama}

Dari movie intro, siswa dapat masuk ke halaman utama dengan Script untuk masuk ke halaman utama sebagai berikut:

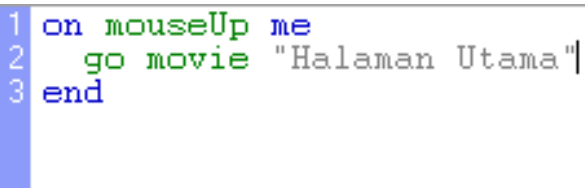

Gambar 18. Action Script Tombol Masuk ke Menu Utama

\section{Action Script tombol Home}

Pada halaman utama ini, terdapat tombol home yang diberi script berikut ini.

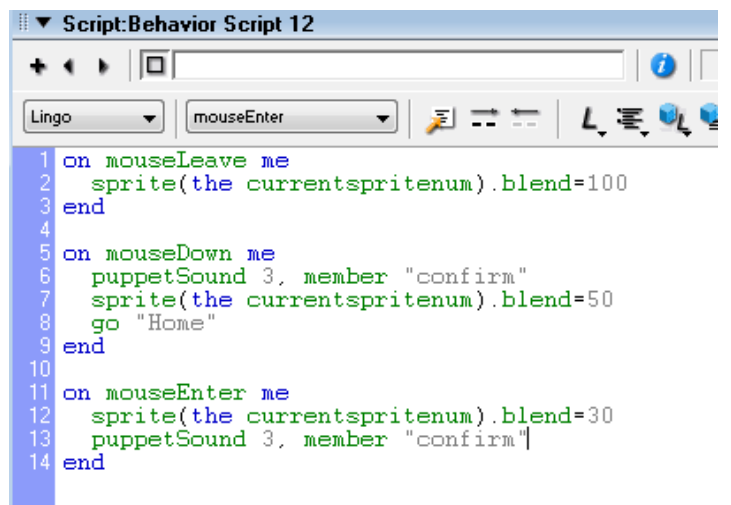

Gambar 19. Action Script Tombol Home

\section{Hasil Uji Validitas dan Reliabilitas}

\section{Hasil Uji Pakar}

Dalam melaksanakan pengujian ini dilakukan oleh 3 orang pakar yang merupakan guru jurusan Multimedia di SMK. Data temuan dari hasil uji pakar dapat dilihat pada tabel berikut ini.

Tabel 2. Data Temuan Hasil Uji Pakar

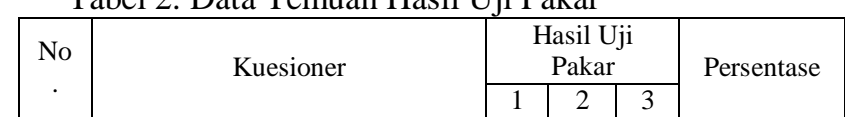




\begin{tabular}{|c|c|c|c|c|c|}
\hline \multirow[t]{2}{*}{ No } & \multirow[t]{2}{*}{ Kuesioner } & \multicolumn{3}{|c|}{$\begin{array}{l}\text { Hasil Uji } \\
\text { Pakar }\end{array}$} & \multirow[t]{2}{*}{ Persentase } \\
\hline & & 1 & 2 & 3 & \\
\hline \multirow[t]{4}{*}{1.} & $\begin{array}{l}\text { Bagaimanakah tampilan CD } \\
\text { Multimedia Interaktif }(\mathrm{CMI}) \\
\text { yang sudah dicobakan? }\end{array}$ & & & & \\
\hline & a. Sangat Menarik & $\sqrt{ }$ & & & $33,3 \%$ \\
\hline & b. Menarik & & $\sqrt{ }$ & $\sqrt{ }$ & $66,7 \%$ \\
\hline & c. Kurang Menarik & & & & \\
\hline \multirow[t]{4}{*}{2.} & $\begin{array}{l}\text { Apakah CMI ini memiliki } \\
\text { kemudahan dalam navigasinya } \\
\text { ? }\end{array}$ & & & & \\
\hline & a. Sangat mudah & $\sqrt{ }$ & $\sqrt{ }$ & $\sqrt{ }$ & $100 \%$ \\
\hline & b. Mudah & & & & \\
\hline & c. Susah & & & & \\
\hline \multirow[t]{4}{*}{3.} & $\begin{array}{l}\text { Apakah CMI ini memiliki } \\
\text { kemudahan dalam presentasi } \\
\text { materi yang disampaikan? }\end{array}$ & & & & \\
\hline & a. Sangat mudah & $\sqrt{ }$ & $\sqrt{ }$ & $\sqrt{ }$ & $100 \%$ \\
\hline & b. Mudah & & & & \\
\hline & c. Susah & & & & \\
\hline \multirow[t]{4}{*}{4.} & $\begin{array}{l}\text { Apakah media ini interaktif } \\
\text { (ada aksi dan reaksi) pada saat } \\
\text { digunakan? }\end{array}$ & & & & \\
\hline & a. Sangat interaktif & $\sqrt{ }$ & & $\sqrt{ }$ & $66,7 \%$ \\
\hline & b. Cukup interaktif & & $\sqrt{ }$ & & $33,3 \%$ \\
\hline & c. Kurang interaktif & & & & \\
\hline \multirow[t]{4}{*}{5.} & $\begin{array}{l}\text { Apakah CMI ini menggunakan } \\
\text { semua aspek multimedia, } \\
\text { seperti teks, gambar, suara, } \\
\text { animasi dan video? }\end{array}$ & & & & \\
\hline & a. Menggunakan semua aspek & $\sqrt{ }$ & $\sqrt{ }$ & $\sqrt{ }$ & $100 \%$ \\
\hline & $\begin{array}{l}\text { b. Menggunakan beberapa } \\
\text { aspek }\end{array}$ & & & & \\
\hline & $\begin{array}{l}\text { c. Hanya menggunakan } \\
\text { sebagian kecil }\end{array}$ & & & & \\
\hline \multirow[t]{4}{*}{6.} & $\begin{array}{l}\text { Bagaimanakah penggunaan } \\
\text { musik dan sound CMI ini? }\end{array}$ & & & & \\
\hline & a. Sangat menarik & $\sqrt{ }$ & & & $33,3 \%$ \\
\hline & b. Menarik & & $\sqrt{ }$ & $\sqrt{ }$ & $66,7 \%$ \\
\hline & c. Kurang menarik & & & & \\
\hline \multirow[t]{4}{*}{7.} & $\begin{array}{l}\text { Apakah CMI ini memiliki nilai } \\
\text { artistik dan estetika yang baik? }\end{array}$ & & & & \\
\hline & a. Sangat baik & & $\sqrt{ }$ & & $33,3 \%$ \\
\hline & b. Baik & $\sqrt{ }$ & & $\sqrt{ }$ & $66,7 \%$ \\
\hline & c. Kurang baik & & & & \\
\hline \multirow[t]{4}{*}{8.} & $\begin{array}{l}\text { Apakah materi yang disajikan } \\
\text { sesuai dengan kurikulum? }\end{array}$ & & & & \\
\hline & a. Sangat sesuai & $\sqrt{ }$ & & $\sqrt{ }$ & $66,7 \%$ \\
\hline & b. Sesuai & & $\sqrt{ }$ & & $33,3 \%$ \\
\hline & c. Kurang sesuai & & & & \\
\hline \multirow[t]{4}{*}{9.} & $\begin{array}{l}\text { Bagaimanakah penggunaan } \\
\text { bahasa dalam CMI ini? }\end{array}$ & & & & \\
\hline & a. Sangat baik & $\sqrt{ }$ & & & $33,3 \%$ \\
\hline & b. Baik & & $\sqrt{ }$ & $\sqrt{ }$ & $66,7 \%$ \\
\hline & c. Kurang Baik & & & & \\
\hline \multirow[t]{4}{*}{10.} & 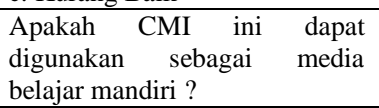 & & & & \\
\hline & a. Sangat bisa & $\sqrt{ }$ & & & $33,3 \%$ \\
\hline & b. Bisa & & $\sqrt{ }$ & $\sqrt{ }$ & $66,7 \%$ \\
\hline & c. Tidak bisa & & & & \\
\hline
\end{tabular}

Dari tabel hasil uji pakar di atas didapatkan respon positif responden kelompok pakar setelah menggunakan CD Multimedia Interaktif. Jawaban responden berada pada pilihan point A atau point B. Dengan demikian, dapat disimpulkan bahwa CD Multimedia Interaktif valid untuk dijadikan sebagai media belajar mandiri bagi siswa dan siswi kelas XI Jurusan Multimedia di SMK jika ditinjau dari uji pakar.

\section{Hasil Uji Pengguna}

Uji pengguna dilakukan dengan mengambil sampel sebanyak $50 \%$ dari jumlah total populasi. Jumlah total siswa yang dijadikan populasi adalah 32 orang, maka diambil sampel 16 orang dari jumlah populasi tesebut. Data temuan dari hasil uji pengguna dapat dilihat pada tabel berikut ini.

Tabel 3. Data Temuan Hasil Uji Pengguna

\begin{tabular}{|c|c|c|c|}
\hline \multirow{2}{*}{ No. } & \multirow{2}{*}{ Kuesioner } & \multicolumn{2}{|c|}{ Hasil Uji Pengguna } \\
\hline & & Hasil & $\begin{array}{c}\text { Persentas } \\
\mathrm{e}\end{array}$ \\
\hline \multirow[t]{4}{*}{1.} & $\begin{array}{l}\text { Bagaimanakah tampilan } \quad \text { CD } \\
\text { Multimedia Interaktif (CMI) yang } \\
\text { sudah dicobakan? }\end{array}$ & & \\
\hline & a. Sangat Menarik & 12 & $75 \%$ \\
\hline & b. Menarik & 4 & $25 \%$ \\
\hline & c. Kurang Menarik & 0 & 0 \\
\hline \multirow[t]{4}{*}{2.} & $\begin{array}{l}\text { Apakah CMI ini memiliki } \\
\text { kemudahan dalam navigasinya? }\end{array}$ & & \\
\hline & a. Sangat mudah & 14 & $88 \%$ \\
\hline & b. Mudah & 2 & $13 \%$ \\
\hline & c. Susah & 0 & 0 \\
\hline \multirow[t]{4}{*}{3.} & $\begin{array}{l}\text { Apakah CMI ini memiliki } \\
\text { kemudahan dalam presentasi materi } \\
\text { yang disampaikan? }\end{array}$ & & \\
\hline & a. Sangat mudah & 12 & $75 \%$ \\
\hline & b. Mudah & 4 & $25 \%$ \\
\hline & c. Susah & 0 & 0 \\
\hline \multirow[t]{4}{*}{4.} & $\begin{array}{l}\text { Apakah media ini interaktif (ada } \\
\text { aksi dan reaksi) pada saat } \\
\text { digunakan? }\end{array}$ & & \\
\hline & a. Sangat interaktif & 13 & $81 \%$ \\
\hline & b. Cukup interaktif & 3 & $19 \%$ \\
\hline & c. Kurang interaktif & 0 & 0 \\
\hline \multirow[t]{4}{*}{5.} & $\begin{array}{l}\text { Apakah CMI ini menggunakan } \\
\text { semua aspek multimedia, seperti } \\
\text { teks, gambar, suara, animasi dan } \\
\text { video? }\end{array}$ & & \\
\hline & a. Menggunakan semua aspek & 14 & $88 \%$ \\
\hline & b. Menggunakan beberapa aspek & 2 & $13 \%$ \\
\hline & $\begin{array}{l}\text { c. Hanya menggunakan sebagian } \\
\text { kecil }\end{array}$ & 0 & 0 \\
\hline \multirow[t]{4}{*}{6.} & $\begin{array}{l}\text { Bagaimanakah penggunaan musik } \\
\text { dan sound CMI ini? }\end{array}$ & & \\
\hline & a. Sangat menarik & 12 & $75 \%$ \\
\hline & b. Menarik & 4 & $25 \%$ \\
\hline & c. Kurang menarik & 0 & 0 \\
\hline \multirow[t]{4}{*}{7.} & $\begin{array}{l}\text { Apakah CMI ini memiliki nilai } \\
\text { artistik dan estetika yang baik? }\end{array}$ & & \\
\hline & a. Sangat baik & 13 & $81 \%$ \\
\hline & b. Baik & 3 & $19 \%$ \\
\hline & c. Kurang baik & 0 & 0 \\
\hline \multirow[t]{4}{*}{8.} & $\begin{array}{l}\text { Apakah materi yang disajikan } \\
\text { sesuai dengan kurikulum? }\end{array}$ & & \\
\hline & a. Sangat sesuai & 14 & $88 \%$ \\
\hline & b. Sesuai & 2 & $13 \%$ \\
\hline & c. Kurang sesuai & 0 & 0 \\
\hline \multirow[t]{4}{*}{9.} & $\begin{array}{l}\text { Bagaimanakah penggunaan bahasa } \\
\text { dalam CMI ini? }\end{array}$ & & \\
\hline & a. Sangat baik & 13 & $81 \%$ \\
\hline & b. Baik & 3 & $19 \%$ \\
\hline & c. Kurang Baik & 0 & 0 \\
\hline 10. & Apakah CMI ini dapat digunakan & & \\
\hline
\end{tabular}




\begin{tabular}{|l|l|c|c|}
\hline \multirow{2}{*}{ No. } & \multicolumn{1}{|c|}{ Kuesioner } & \multicolumn{2}{|c|}{ Hasil Uji Pengguna } \\
\cline { 3 - 4 } & & Hasil & $\begin{array}{c}\text { Persentas } \\
\text { e }\end{array}$ \\
\hline & sebagai media belajar mandiri ? & & \\
\hline & a. Sangat bisa & 13 & $81 \%$ \\
\hline & b. Bisa & 3 & $19 \%$ \\
\hline & c. Tidak bisa & 0 & 0 \\
\hline
\end{tabular}

Dari data di atas dilakukan pengolahan nilai validitas dengan asumsi kesalahan $5 \%$, nilai $\mathrm{r}_{\text {kritis }}=0,3$. Nilai hasil uji validitas yang didapat adalah $r_{\text {hitung }}=0,8$.

Berdasarkan hasil yang didapat $r_{\text {hitung }}$ lebih besar dari $\mathrm{r}_{\text {kritis }}$ maka dapat disimpulkan bahwa CD Multimedia Interaktif ini valid dan layak digunakan sebagai media belajar mandiri untuk siswa dan siswi kelas XI Jurusan Multimedia SMK Kabupaten Dharmasraya.

\section{Hasil Uji Reliabilitas}

Uji reliabilitas CD Multimedia Interaktif dilakukan dengan mengolah data temuan uji kelayakan. Nilai hasil uji reliabilitas yang didapat adalah $r_{\text {hitung }}=1,027$. Nilai ini memiliki reliabilitas yang tinggi karena $\mathrm{r}_{\text {hitung }}$ lebih besar dari nilai $r_{\text {tabel. }}$. Dimana nilai $r_{\text {tabel }}$ yang digunakan adalah 0,468 .

\section{Penutup}

Kesimpulan yang dapat diambil dari rancangan aplikasi CD pembelajaran multimedia interaktif ini antara lain :

1. Proses rancang bangun $\mathrm{CD}$ interaktif multimedia pembelajaran ini menggunakan prosedur teknis pembelajaran multimedia interaktif yaitu : a) Analisis kebutuhan, b) Identifikasi materi, c) Menentukan model pembelajaran, d) Desain flowchart, e) Penulisan storyboard, f) Pengumpulan bahan grafis, g) Pengumpulan bahan animasi, h) Pemograman, i) Finishing dan mastering, j) Uji coba, k) revisi produk akhir.
2. Perancangan dan pembuatan $C D$ Interaktif menggunakan beberapa aplikasi desain grafis dan multimedia antara lain : Coreldraw, Photoshop, Camtasia, Adobe After Effect, Macromedia Director.

3. Hasil pretest mata pelajaran Pengolahan Citra Digital Siswa SMK N Kab. Dharmasraya menunjukan sebesar 11 orang (40,74\%) yang melebih nilai Kriteria Ketuntasan Minimal (KKM).

4. Hasil Posttest mata pelajaran Pengolahan Citra Digital Siswa SMK N Kab. Dharmasraya setelah menggunakan $\mathrm{CD}$ Interaktif sebesar 21 orang (77,78\%) yang melebihi nilai KKM.

\section{DAFTAR PUSTAKa}

[1] Darma Putra. 2010. "Pengolahan Citra Digital". Jogyakarta: Andi Offset.

[2] Deni Darmawan. 2012. Teknologi Pembelajaran. Bandung: PT. Remaja Rosdakarya.

[3] Endah Damayanti. 2013. Pengolahan Citra Digital". Direktorat Jenderal Peningkatan Mutu Pendidik \&Tenaga Kependidikan: Jakarta

[4] Hendi Hendratman. 2008. The Magic of Macromedia Director. Bandung: Informatika Bandung.

[5] __ 2006. Tips n Trix Computer Graphics Design. Bandung: Informatika Bandung.

[6] Juhaeri Susanto. 2007. "Pengantar Multimedia Untuk Media Pembelajaran". http://www.unej.ac.id/files/pdf2/ juhaeri-PengantarMultimedia-Untuk-Media-Pembelajaran-Bag2.pdf, diakses September 2014.

[7] Septiana Firdaus. dkk. 2012, "Perancangan Aplikasi Multimedia Interaktif Company Profile Generic (Studi Kasus CV. Ganetic).” Jurnal Algoritma. (No. 09 tahun 2012). Hlm. $1-2$ 